\title{
PERAN KOPERASI SYARIAH BAITUL TAMWIL MUHAMMADIYAH TERHADAP PEMBERDAYAAN USAHA KECIL DAN MENENGAH DI BANDAR LAMPUNG
}

\author{
Nur Syamsiyah, ${ }^{1}$ Annisa Martina Syahrir, ${ }^{2}$ Is Susanto ${ }^{3}$ \\ ${ }^{1}$ Sekolah Tinggi Ekonomi dan Bisnis Islam (STEBI) Lampung \\ nursyamsiyah@stebilampung.ac.id \\ ${ }^{2}$ Sekolah Tinggi Ekonomi dan Bisnis Islam (STEBI) Lampung \\ annisa@ @stebilampung.ac.id \\ ${ }^{3}$ UIN Raden Intan Lampung \\ issusanto@radenintan.ac.id
}

\begin{abstract}
The results showed that sharia cooperatives have a huge potential and role in the effort to support the empowerment of SMEs in Bandar Lampung, this can be seen from the SME financing report data at the research location before and after obtaining financing from the BTM Syariah Cooperative which also helps SME development and empowerment practices UKM conducted by Koperasi Syariah BTM Bandar Lampung which provides service financing to the public, namely business credit programs with an agreed profit sharing ratio of 30:70 with a margin of $18 \%$ per year. The role of the BTM Lampung Cooperative in empowering SMEs according to the Islamic economic perspective is the sharia cooperative based on the Quran and as-Sunnah namely: Mutual help (ta'wun) and mutually reinforcing (tafakul) based on the Quran al-Maidah (5) verse 2. BTM Bandar Lampung Islamic Cooperative also upholds justice and rejects any religious forms and concentrates economic funding sources on only a few people or groups of people. This is based on the Quran letter al-Rum verse 39.
\end{abstract}

Keywords: Sharia Cooperative, Baitul Tamwil Muhammadiyah, Small and Medium Enterprises.

\begin{abstract}
ABSTRAK
Hasil penelitian menunjukkan bahwa koperasi syariah memiliki potensi dan peranan yang sangat besar dalam upaya mendukung pemberdayaan UKM di Bandar Lampung, hal ini terlihat dari data laporan pembiayaan UKM di lokasi penelitian sebelum dan sesudah mendapatkan pembiyaan dari Koperasi Syariah BTM yang juga membantu pengembangan UKM dan praktek pemberdayaan UKM yang dilakukan oleh Koperasi Syariah BTM Bandar Lampung yang memberikan pembiayaan jasa layanan kepada masyarakat yaitu program kredit usaha dengan nisbah bagi hasil yang disepakati 30:70 dengan marjin 18\% pertahun. Peranan Koperasi Syariah BTM Lampung dalam pemberdayaan UKM menurut perspektif ekonomi Islam yaitu koperasi syariah berdasarkan al-Quran dan as-Sunah yaitu: Saling tolong menolong ( $t a$ 'wun) dan saling menguatkan (tafakul) yang didasarkan pada al-Quran surat al-Maidah (5) ayat 2. Koperasi syariah BTM Bandar Lampung juga menjunjung tinggi keadilan serta menolak setiap bentuk ribawi dan pemusatan sumber dana ekonomi pada segelintir orang atau sekelompok orang saja. Hal ini di dasarkan pada al-Quran surat al-Rum ayat 39.
\end{abstract}




\section{A. PENDAhULUAN}

Di Indonesia, sistem dan praktik ekonomi syariah telah dikenal oleh masyarakat dan mengalami perkembangan yang begitu pesat. Perkembangan ini tidak terlepas dari alasan pokok keberadaan sistem ekonomi syariah, yaitu keinginan dari masyarakat muslim untuk kaffah (menyeluruh) dalam menjalankan ajaran Islam dengan menjalankan aktivitas dan transaksi ekonominya sesuai dengan ketentuan syariah. Islam adalah agama yang komprehensif, yang memberikan tuntutan hampir seluruh aspek kehidupan manusia, termasuk tuntutan dalam transaksi dan kegiatan ekonomi yang menjadi bagian penting dari kehidupan. ${ }^{1}$

Tujuan kehidupan manusia adalah tercapainya kebahagiaan hidup di dunia dan di akherat. Dan untuk mencapai kebahagiaan hidup manusia agar terealisasikan, materi bukan satu-satunya isi dari kebahagiaan itu, akan tetapi materi merupakan salah satu faktor penunjang yang dapat mewujudkan kebahagiaan manusia. Hal ini disebabkan karena kebahagiaan manusia dapat terwujud apabila tujuan-tujuan materi manusia dapat terealisasikan. Tujuan tersebut antara lain pengentasan kemiskinan, pemenuhan kebutuhan bagi setiap manusia, dan tersedianya peluang bagi setiap manusia untuk hidup terhormat serta distribusi pendapatan kekayaan yang adil dan merata. ${ }^{2}$

Salah satu upaya untuk mencapai tujuan hidup manusia tersebut, perlu adanya kesempatan bagi masyarakat untuk berusaha sesuai dengan kemampuannya dan keahlian yang mereka miliki. Salah satunya yaitu melalui kegiatan Usaha Kecil dan Menengah (UKM). Namun pada sisi lain, kemunculan kegiatan Usaha Kecil dan Menengah (KM) mengalami tantangan tersendiri dalam menghadapi persaingan dengan pelaku dan pengusaha besar. Oleh sebab itu, perlu adanya mitra usaha yang dapat membantu dalam menghadapi persaingan dengan pengusaha besar, terutama dalam hal permodalan, manajemen, dan pemberdayaan UKM.

Melihat problem di atas, dibutuhkan suatu lembaga khusus yang dapat menampung serta membantu masyarakat para pelaku usaha Kecil dan Menengah dalam menghadapi perkembangan zaman dimasa mendatang. Dengan adanya kesempatan dan pemberdayaan para pelaku usaha kecil dan menengah, diharapkan pelaku usaha mampu menghadapi persaingan dengan pelaku usaha besar dan mampu menciptakan produktifitas yang memunculkan peluang usaha dan kesempatan kerja yang lebih luas bagi masyarakat, dan pada akhirnya akan turut serta membantu pemerintah dalam mengurangi angka pengangguran.

Berkenaan dengan masalah tersebut, bagi pengusaha kecil terdapat berbagai lembaga keuangan yang dapat menampung dan memberikan kesempatan bagi para pelaku usaha kecil dan menengah dalam membantu perkembangan UKM, diantaranya adalah Koperasi Syariah. Koperasi Syariah merupakan badan usaha atau badan hukum yang memiliki anggota orang-perorang yang dalam pelaksanaan kegiatannya dengan berdasarkan pada prinsip syariah sekaligus sebagai gerakan ekonomi rakyat yang berdasarkan pada asas kekeluargaan. Koperasi sebagai badan usaha dan gerakan ekonomi rakyat memiliki berbagai peran demi mewujudkan masyarakat adil dan makmur, serta sejahtera.

Secara umum konsep utama koperasi syariah adalah menggunakan akad Shirkah Mufawadah yakni sebuah usaha yang didirikan bersama-sama oleh dua orang atau lebih, masing-masing memberikan kontribusi dana dalam porsi yang sama besar dan berpartisipasi dalam kerja dengan bobot yang sama pula. Masing-masing partner saling

\footnotetext{
${ }^{1}$ Ibrahim Lubis, Ekonomi Islam Suatu Pengantar (Jakarta: Kalam Mulai, 1994). 1.

${ }^{2}$ Umar Chapra, Islam dan Tantangan Ekonomi (Jakarta: Gema Insani, 2000). 1.
} 
menanggung satu sama lain dalam hak dan kewajiban dan tidak diperkenanka salah seorang memasukkan modal yang lebih besar dan memperoleh keuntungan yang lebih besar pula dibandingkan dengan partner lainnya.

Keberadaan koperasi syariah ditengah-tengah masyarakat memiliki peran yang sangat strtaegis, yaitu menjauhkan masyarakat dari praktik non-syariah, melakukan pembinaan dan pendanaan usaha kecil, melepaskan ketergantungan pada rentenir dan lintah darat, dan menjaga keadilan ekonomi masyarakat dengan distribusi yang merata. Dan salah satu koperasi syariah yang melaksanakannya peranan tersebut adalah koperasi syariah Baitul Tamwil Muhammadiyah Bandar Lampung.

Koperasi syariah Baitul Tamwil Muhammadiyah (BTM) adalah suatu lembaga keuangan yang menjalankan prinsip kegiatannya berdasarkan prinsip-prinsip syariah. Pada awal berdirinya koperasi syariah BTM yakni bertujuan untuk membantu mengembangkan usaha kecil serta melayani kebutuhan keuangan bagi golongan ekonomi lemah yang tidak terjangkau oleh bank umum yaitu menjadi lembaga yang akan memberikan layanan keuangan kepada masyarakat dan memberi solusi permodalan bagi sektor riil, yaitu bagi usaha kecil dan menengah seperti pedagang, petani, pegawai dan rekan-rekan koperasi dan juga menjadi perantara kerjasama antar Shahibul Mal (pemilik dana) dan Mudarib (pelaksana usaha) secara konsisten berperan aktif dalam pembangunan nasional.

Melihat fenomena dan realita yang ada menjadi motivasi bagi peneliti untuk melakukan penelitian dan pengkajian secara mendalam terkait dengan keberadaan koperasi syariah Baitul Tamwil Muhammadiyah, terutama yang menjadi titik fokus penelitian ini adalah peranan koperasi syariah Baitul Tamwil Muhammadiyah dalam pemberdayaan usaha kecil dan menengah di Bandar Lampung serta hal-hal terkait di dalamnya dengan menggunakan kaca mata ekonomi Islam. Hal ini dimaksudkan untuk mengetahui sejauh mana peran yang dilaksanakan oleh koperasi syariah Baitul Tamwil Muhammadiyah dalam pemberdayaan usaha kecil dan menengah di Bandar Lampung.

\section{B. LANDASAN TEORI}

Koperasi berasal dari perkataan co dan operation, yang mengandung arti kerja sama untuk mencapai tujuan. Koperasi adalah suatu perkumpulan yang beranggotakan orang-orang atau badan-badan, yang memberikan kebebasan masuk dan keluar sebagai anggota, dengan bekerja sama secara kekeluargaan menjalankan usaha, untuk mempertinggi kesejahteraan jasmaniah para anggotanya. ${ }^{3}$ Definisi tersebut mengandung unsur-unsur bahwa: Koperasi bukan merupakan perkumpulan modal (bukan akumulasi modal), akan tetapi persekutuan sosial, sukarela untuk menjadi anggota, netral terhadap aliran dan agama, dan tujuannya mempertinggi kesejahteraan jasmaniah anggota-anggota dengan kerja sama secara kekeluargaan.

Koperasi juga dapat berarti usaha bersama yang berarti segala pekerjaan yang dilakukan secara bersama-sama sebenarnya dapat disebut koperasi. Namun demikian, yang dimaksud koperasi disini adalah suatu bentuk peraturan dan tujuan tertentu pula, perusahaan yang didirikan oleh orang-orang tertentu, untuk melakukan kegiatan-kegiatan tertentu.

Menurut Muhammad Hatta sebagaimna adikutip oleh Arifin Satio dan Halomon Tamba mengatakan bahwa koperasi adalah: Usaha bersama yang memperbaiki nasib

${ }^{3}$ Ninik Widiyanti dan Y. W. Sunindhia, Koperasi dan Perekonomian Indonesia, 2008. 1. Rijal Yahya dkk., Akuntansi Perbankan Syariah Teori dan Praktik, 2016. 1. 
penghidupan ekonomi berdasarkan tolong menolong. ${ }^{4}$ Koperasi merupakan salah satu bentuk badan hukum yang sudah lama dikenal di Indonesia. Pelopor pengembangan perkoperasian di Indonesia adalah Bung Hatta, dan sampai saat ini beliau sangat dikenal dengan sebutan Bapak Koperasi Indonesia. ${ }^{5}$

Berdasarkan definisi tersebut, maka dapat penulis simpulkan bahwa koperasi syariah adalah Usaha bersama yang teroganisir secara mantap, demokratis, otonom, partisifatif dan berwatak sosial yang operasionalnya menggunakan prinsip-prinsip yang mengusung etika moral dengan memperhatikan halal atau haramnya sebuah usaha yang dijalankannya sebagaimana diajarkan dalam agama Islam. ${ }^{6}$

Koperasi syariah lebih dikenal dengan nama KJKS (Koperasi Jasa Keuangan Syariah) dan UJKS (Unit Jasa Keuangan Syariah Koperasi). Koperasi Jasa Keuangan Syariah adalah koperasi yang kegiatan usahanya bergerak di bidang pembiayaan, investasi, dan simpanan sesuai pola bagi hasil (syariah). Unit Jasa Keuangan Syariah adalah usaha pada koperasi yang kegiatan usahanya bergerak di bidang pembiayaan, investasi, dan simpanan sesuai dengan pola bagi hasil (syariah), sebagai bagian dari kegiatan usaha koperasi yang bersangkutan. ${ }^{7}$

Koperasi syariah adalah badan usaha yang beranggotakan orang-orang atau badan hukum koperasi dengan melandaskan kegiatannya berdasarkan prinsip syariah sekaligus gerakan ekonomi rakyat yang berdasarkan asas kekeluargaan. Koperasi bertujuan untuk mensejahterakan anggotanya, yang meliputi, antara lain: Perorangan, yaitu orang yang secara sukarela menjadi anggota koperasi; Badan Hukum Koperasi, yaitu suatu koperasi yang menjadi anggota yang memiliki lingkup lebih luas.

Umumnya koperasi, termasuk koperasi syariah dikendalikan secara bersama oleh seluruh anggotanya, dimana setiap anggota memiliki hak suara yang sama dalam setiap keputusan yang diambil koperasi. Pembagian keuntungan koperasi biasa disebut Sisa Hasil Usaha (SHU) dihitung berdasarkan andil anggota tersebut dalam koperasi. Koperasi syariah di Indonesia sering disebut dengan Baitul Maal Wa At-Tamwil atau BMT, karena dalam realitanya Koperasi Syariah banyak yang berasal dari konversi Baitul Maal Wa At-Tamwil.

Rijal Yahya dkk. dalam bukunya Akuntansi Perbankan Syariah Teori dan Praktik Kontemporer menyebutkan bahwa Baitul wat Tamwil (BMT), atau disebut juga dengan "Koperasi Syariah", merupakan lembaga keuangan syariah yang berfungsi menghimpun dan menyalurkan dana kepada anggotanya dan biasanya beroperasi dalam skala mikro. ${ }^{8}$

Secara umum, prinsip operasional koperasi syariah atau Baitul Maal Wa At-Tamwil adalah membentuk kesejahteraan para anggota dalam bentuk gotong royong dan tetntunya prinsip tersebut tidak menyimpang dari sudut pandang prinsip syariah yaitu prinsip gotong royong (Ta'awun ala al-Birri) dan bersifat kolektif (Berjamaah) dalam membangun kemandirian hidup. Melalui hal inilah, perlu adanya proses internalisasi terhadap pola pemikiran, tata cara pengolaan, produk-produk, dan hukum yang diperlukan harus sesuai dengan syariat. Dengan kata lain koperasi syariah merupakan

${ }^{4}$ Arifin Satio dan Halomon Tamba, Koperasi Teori dan Praktik (Jakarta: Glora Aksara Pratama, 2001). 15 .

${ }^{5}$ Kasmir, Bank dan Lembaga Keuangan Lainnya (Jakarta: Rajawali Pers, 2013). 254.

${ }^{6}$ Nur S. Buchori, Koperasi Syariah (Jawa Timur: Masmedia Buana Pustaka, 2009). 12

7 Triana Sofiani, "Kontruksi Norma Hukum Koperasi Syariah dalam Kerangka Sistem Hukum Koperasi Nasional,” Jurnal Hukum Islam 12 (Desember 2014). 136.

${ }^{8}$ Rijal Yahya dkk., Akuntansi Perbankan Syariah Teori dan Praktik. 20. 
sebuah konversi dari koperasi konvensional melalui pendekatan yang sesuai dengan syariat Islam dan peneladanan ekonomi yang dilakukan Rasulullah dan para sahabatnya. ${ }^{9}$

Falsafah adalah keyakinan terhadap nilai-nilai yang menjadi persoalan suatu tujuan dan dipakai sebagai pandangan hidup. Koperasi syariah yang mempunyai basis kegiatan ekonomi rakyat dengan falsafah "dari anggota oleh anggota untuk anggota", maka konsep pemasaran pada koperasi syariah merupakan falsafah usaha yang menyatakan bahwa banyaknya transaksi yang terjadi adalah syarat utama bagi kelangsungan sebuah koperasi syariah.

Koperasi syariah mempunyai prinsip saling menolong dan tidak dibenarkan mencari keuntungan di antara keduanya, karena setiap transaksi (Tasarruf) didasarkan atas penggunaan yang efektif apakah untuk pembiayaan ataupun kebutuhan sehari-hari, kedua hal tersebut diperlukan secara berbeda. Untuk Usaha produktif, misalnya anggota mau berdagang maka dapat menggunakan prinsip bagi hasil (Musharakah atau Mudarabah) sedangkan untuk pembelian alat transportasi atau pun alat-alat lainnya dapat menggunakan prinsip jual-beli (Murabahah). Prinsip tersebut diterapkan untuk anggota koperasi, dan salah satunya adalah pelaku usaha mikro dan menengah.

Menurut UU Nomor 20 Tahun 2008 tentang Usaha Mikro, Kecil dan Menengah bahwa yang dimaksud ussaha Mikro adalah usaha produktif milik orang perorang dan atau badan usaha perorangan yang memenuhi kriteria Usaha Mikro sebagaimana diatur dalam UU ini. Usaha Kecil adalah usaha ekonomi produktif yang berdiri sendiri, yang dilakukan oleh orang perorang atau badan usaha yang bukan merupakan badan anak perusahaan atau bukan cabang perusahaan yang dimiliki, dikuasai, atau menjadi bagian langsung maupun tidak langsung dari Usaha Menengah atau Usaha Besar yang memenuhi kriteria Usaha Kecil sebagaimana dalam Undang-Undang.

Asas dan tujuan dalam Usaha Mikro, Kecil dan Menengah menurut ketentuan UU berdasarkan pada sistem kekeluargaan, demokrasi ekonomi, kebersamaan, efesiensi berkeadilan, berkelanjutan, berwawasan lingkungan, kemandirian, keseimbangan kemajuan dan kesatuan ekonomi nasional.

Tujuan pemberdayaan usaha Mikro, Kecil dan Menengah yaitu mewujudkan struktur perekonomian nasional yang seimbang, berkembang dan berkeadilan; menumbuhkan dan mengembangkan kemampuan usaha Mikro, kecil dan Menengah menjadi usaha yang tangguh dan mandiri, meningkatkan peran Usaha Mikro, Kecil dan Menengah dalam pembangunan daerah, penciptaan lapangan kerja, pemerataa pendapatan, pertumbuhan ekonomi dan pengentasan rakyat dari kemiskinan.

\section{METODOLOGI PENELITIAN}

Jenis penelitian ini adalah penelitian lapangan (field research), yaitu penelitian yang objeknya mengenai gejala-gejala atau peristiwa-peristiwa yang terjadi peda kelompok masyarakat. Sehingga penelitian ini juga bisa disebut penelitian kasus atau study kasus (case study) dengan pendekatan deskritif-kualitatif. Sedangkan sifat penelitian ini yaitu deskriptif analitik, yaitu menggambarkan tentang suatu masyarakat, kelompok, orang tertentu atau gambaran tentang suatu gejala atau hubungan antara dua gejala atau lebih.

Populasi dalam penelitian ini yaitu masyarakat yang memiliki Usaha Kecil dan Menengah serta menggunakan modal dari koperasi syariah Baitul Tamwil Muhammadiyah Bandar Lampung, dan petugas yang ada pada koperasi syariah Baitu

\footnotetext{
${ }^{9}$ M. Ali. Hasan, Berbagai Macam Transaksi Dalam Islam (Jakarta: Raja Grafindo Persada, 2003).
} 161. 
Tamwil Muhammadiyah diantaranya direktur, manajer serta petugas pembiayaan. Dari kerseluruhan populasi yang ada, penulis akan menjadi 20 orang sampel dalam penelitian ini untuk membantu.

Berdasarkan sampel diatas maka dalam penelitian ini penulis menetapkan sampel sebanyak $10 \%$ untuk pengusaha kecil yang menggunakan dana dari koperasi syariah baitul tamwil muhammadiyah bandar Lampung dengan perincian 200 orang $\mathrm{x} 10 \%=20$ orang, jadi jumlah sampelnya 20 orang.

Metode pengumpulan data dalam penelitian ini yaitu metode interview, metode observasi dan metode dokumentasi. Metode interview adalah suatu proses tanya jawab dalam penelitian yang berlangsung secara lisan dalam mana dua orang atau lebih bertatap muka mendengarkan secara langsung informasi-informasi keterangan-keterangan yang dipertanyakan. Metode interview yang dipergunakan dalam penelitian ini adalah interview yang bebas terpimpin, yaitu kombinasi antara wawancara bebas terpimpin, maksudnya wawancara yang dilakukan dengan membawa pertanyaan lengkap dan terperinci, serta bebas menanyakan apa saja dan pertanyaan masih dapat berkembang sesuai dengan jawaban yang diberikan responden selama masih terikat dengan permasalahan yang diteliti.

Metode observasi yaitu usaha-usaha mengumpulkan data dengan pengamatan dan pencatatan secara sistematis terhadap fenomena-fenomena yang diselidiki. Dalam hal ini, penulis mengadakan pengamatan terhadap kondisi wilayah penelitian secara langsung serta mencatat peristiwa-peristiwa yang berkaitan dengan objek penelitian. Observasi dilakukan di koperasi syariah BTM Bandar Lampung untuk mencari data nasabah pembiayaan UKM yang berkaitan disalurkan oleh koperasi syariah BTM Bandar Lampung. Sedangkan metode dokumentasi adalah metode yang digunakan untuk memperoleh data secara tertulis yang berupa surat-surat, catatan harian, laporan artikel dan lain sebagainya yang merupakan data yang berbentuk tulisan.

Analisis data dalam penelitian ini menggunakan pola fikir deduktif yaitu berangkat dari peristiwa-peristiwa yang umum untuk memperoleh pengertian secara menyeluruh yang bersifat khusus. Sehingga menghasilkan data deskriptif berupa uraian kalimat tertulis ataupun lsan tentang orang-orang dan perilaku yang diamati. Maksudnya adalah penulis akan menghimpun informasi berkaitan dengan judul yang penulis ambil, setelah itu penulis akan mengumpulkan informasi tersebut sehingga menjadi suatu kesimpulan yang bersifat khusus yang dapat dimengerti dan dipahami.

\section{HASIL PENELITIAN}

Secara defakto koperasi syari`ah telah ada sejak bulan Februari 2004, meskipun pada waktu itu namanya belum koperasi melainkan Lembaga Keuangan Syari ah (LKS). Ini ditandai dengan mulainya pembiayaan pada pedagang-pedagang kecil yang ada dipasar Tradisional Way Halim Bandar Lampung. Pada mulanya lembaga ini mendapatkan pinjaman dana dari Majelis Ekonomi (ME) Muhammadiyah Wilayah Bandar Lampung sebesar Rp.2.000.000,00 (Dua Juta Rrupiah). Dengan dana itulah LKS menjalankan fungsinya sebagai lembaga keuangan yang bergerak dalam bidang jasa keuangan khususnya pembiayaan usaha yang berpola syari ah.

Melihat respon masyarakat yang cukup bagus atas kehadiran LKS, kemudian ME Muhammadiyah Wilayah Lampung menambah investasinya sebesar Rp. 5.000.000,00 (Lima Juta Rupiah), menjadi Rp. 7.000.000,00 (Tujuh Juta Rupiah) dibulan ketiga, sehingga LKS dapat memberikan pinjaman lebih banyak kepada pedagang. Setelah berjalan sektar 6 bulan, mulai ada pihak lain yang tertarik menginvestasikan dana pada LKS. Meskipun jumlah investasinya tidak banyak, namun kami jadikan dukungan moral 
untuk mengembangkan LKS agar menjadi lembaga keuangan yang lebih besar. Pada bulan Mei 2005, ME Muhammadiyah Wilayah lampung sebagai pemprakasa berdirinya LKS ini mengundang beberapa orang anggota perserikatan Muhammadiyah untuk diajak mengembangkan LKS agar ruang lingkup kerjanya lebih luas dan memiliki payung hukum dalam beraktifitas. Setelah beberapa tahapan pada bulan agustus 2005 terbentuklah koperasi dengan nama Koperasi Syari ah Baitul Tamwil Muhammadiyah (BTM) dengan badan hukum, 04/BH/DKPM/XX/2005, koperasi ini bergerak dengan menggunakan pola syari`ah.

Koperasi Syariah BTM mempunyai peran dan tujuan sebagai suatu lembaga pemberdayaan umat tentunya tidak terlepas dari Visi dan Misi Koperasi Syariah BTM itu sendiri. Adapun Visi Koperasi Syari ah BTM adalah menjadi koperasi syariah baitul tamwil terbesar di Lampung, sedangkan misi Koperasi Syari ah BTM yaitu menciptakan peluang usaha bagi masyarakat, menciptakan sumber daya yang visioner, prospektif dan produktif, serta memberikan solusi bagi masyarakat khusunya bagi anggotanya agar terhindar dari praktek riba.

Demi mencapai visi, misi dan tujuan Koperasi Syariah BTM Bandar Lampung, maka koperasi melaksanaan pemberdayaan bagi masyarakat usaha mikro dan menengah. Pembedayaan UKM yang ada pada Koperasi Syarian Baitul Tamwil Muhammadiyah Bandar Lampung adalah suatu bentuk pinjaman modal kepada masyarakat yang membutuhkan, yang digunakan untuk kegiatan produksi usahanya. Jadi pemberdayaan UKM adalah peminjaman modal untuk pengembangan usahanya terhadap masyarakat kecil dan menengah sehingga mampu tumbuh dan berkembang menjadi usaha yang tangguh dan mandiri.

Pelaku usaha atau mudarib sebagai pihak yang dapat dibiayai oleh koperasi syariah BTM Bandar Lampung adalah investasi dan modal kerja untuk dana usaha yang banyak dibiayai secara ekonomis, pembiayaan produktif untuk pengusaha kecil, pedagang kaki lima dan usaha mikro yang produktif lainnya, pembiayaan investasi atau konsumtif bagi golongan berpenghasilan tetap baik dari pegawai, PNS dan pegawai swasta, dan nasabah secara umum yang layak dibiayai secara ekonomis.

Peranan Koperasi Syariah BTM Bandar Lampung terhadap pemberdayaan UKM di Bandar Lampung yaitu pembiayaan yang disalurkan oleh BTM secara garis besar terdiri dari Usaha Kecil dan Menengah (UKM) dan non-UKM. Menurut hasil yang penelitian di lapangan diperoleh data bahwa potensi Koperasi Syariah sangat berperan terhadap pertumbuhan ekonomi masyarakat, hal ini dilihat dari laporan komposisi pembiayaan UKM dan kontribusi UKM dan besar terhadap BPD pada Koperasi Syariah BTM Bandar Lampung dari tahun ketahun sesudah adanya Koperasi Syariah, terutama sektor perdagangan yang mendominasi penyaluran UKM semula 17.670 naik menjadi 26.400 UKM. Khusus pembiayaan untuk UKM dilakukan dengan beberapa prinsip akad, diantaranya prinsip murabahah yaitu pembiayaan dengan prinsip jual beli barang pada harga asal dengan tambahan keuntungan yang disepakati, dengan pihak bank selaku penjual dan nasabah selaku pembeli. Pembayaran dapat dilakukan secara angsuran sesuai dengan kesepakatan.

Pembiayaan UKM yang disalurkan oleh Koperasi Syariah BTM Bandar Lampung secara garis besar tediri dari UKM dan non-UKM. Khusus pembiayaan UKM dilakukan dengan akad murabahah yang merupakan produk unggulan koperasi syariah BTM Bandar Lampung. Jadi, secara garis besar tampak bahwa awalnya perhatian BTM Koperasi Syariah terhadap pemberdayaan UKM sudah bagus dan mengalami peningkatan yang signifikan. Hal tersebut mengindikasikan bahwa komposisi kedua tabel di atas sangat berperan dalam pemberdayaan UKM. 
Secara garis besar tampak bahwa pada awalnya perhatian Koperasi Syariah BTM Bandar Lampung cukup besar dan dari tahun ke tahun mengalami peningkatan yang cukup signifikan. Hal ini juga mengindikasikan bahwa Koperasi Syariah BTM Bandar Lampung menjalankan fungsi sosialnya dengan cara meningkatkan pembiayaan untuk UKM dan sesudah memberikan pembiayaan pada nasabah Koperasi Syariah BTM melakukan survei lapangan memberikan penyuluhan dan pendampingan terhadap nasabah agar nasabah memanfaatkan dana yang diberikan tersebut untuk perkembangan usahanya. Keberpihakan Koperasi Syariah BTM terhadap UKM dan ekonomi syariah terwujud dalam visi dan misi Koperasi Syariah BTM Bandar Lampung. Salah satu wujud nyata bahwa Koperasi Syariah BTM Bandar Lampung sangat berperan terhadap pemberdayaan usaha kecil dan menengah di Bandar Lampung yaitu melalui Kredit Usaha Rakyat, diantaranya dari hasil wawancara dengan beberapa nasabah dan salah satunya adalah Bapak Amad Fadholi yang melakukan transaksi pembiayaan dengan pihak Koperasi dengan prinsip bagi hasil. Nisbah yang telah disepakati yaitu 30:70 dengan marjin $18 \%$ pertahun, pembiayaan digunakan untuk menembangkan usahanya disektor perdagangan pertanian. Dengan adanya pembiayaan tersebut usaha Bapak Fadholi menjadi lebih berkembang dan terbentu dari kondisi sebelumnya yang belum memenuhi kebutuhannya, dan di samping itu jangka waktu angsuran pengembalian pinjaman sangat efisien bagi nasabah. Sehingga dengan adanya pembiayaan UKM yang disalurkan oleh Koperasi Syariah BTM Bandar Lampung Bapak Fadholi menambah jumlah usahanya.

Demi mengoptimalkan peranannya terhadap pemberdayaan UKM, Koperasi Syariah BTM Bandar Lampung memiliki kerja sama yang dilakukan dalam bentuk: Kerja sama dengan linkage dengan lembaga keuangan syariah, kerja sama dengan lembaga pendamping LKSM, dan kerja sama dengan perusahaan-perusahaan dalam rangka kemitraan.

Di samping model kerja sama tersebut bentuk lainnya yang dilakukan dengan beberapa BMT yang bersifat khusus. Keberadaan Koperasi Syariah ini dalam kapasitasnya sebagai mitra bagi pengembangan LKSM menjadi sangat penting. Dari penelitian pembiayaan Koperasi Syariah terhadap UKM diharapkan lebih optimal, karena Koperasi Syariah Memiliki keahlian dan pengalaman dalam menangani pembiayaan UKM. Kerja sama ini diharapkan menciptakan sinergi dalam penyaluran pembiayaan terhadap UKM.

Hasil analisis di atas, maka dapat dikaitkan bahwa dalam penyaluran pemberdayaan UKM yang terjadi di Koperasi Syariah BTM Bandar Lampung tergolong pembiayaan murabahah dan mudarabah yang merupakan produk pembiayaan Koperasi Syariah BTM Bandar Lampung yang diprioritaskan pada sektor jasa, perdagangan dan pertanian terutama untuk modal kerja bagi masyarakat menengah ke bawah di Bandar Lampung.

Pemberdayaan adalah upaya untuk meningkatkan harkat dan martabat lapisan masyarakat dalam kondisi yang kurang mampu melepaskan diri dari perangakap kemiskinan dan keterbelakangan, dengan kata lain memberdayakan adalah memampukan dan memandirikan masyarakat. Atau sistem tindakan nyata yang menawarkan alternatif model pemecahan masalah ummah dalam bidang sosial, ekonomi, dan lingkungan dalam perspektif ekonomi Islam.

Pemberdayaan umat adalah upaya untuk meningkatkan harkat dan martabat lapisan masyarakat dalam kondisi yang kurang mampu melepaskan diri dari perngakap kemiskinan dan keterbelakangan, dengan kata lain memberdayakan adalah memampukan dan memandirikan masyarakat. Atau sistem tindakan nyata yang menawarkan alternatif 
model pemecahan masalah ummah dalam bidang sosial, ekonomi, dan lingkungan dalam perspektif ekonomi Islam.

Dengan demikian, pengembangan atau pemberdayaan masyarakat Islam merupakan model empiris pengembangan prilaku individual dan kolektif dalam dimensi amal soleh (karya terbaik), dengan titik tekan pada pemecahan masalah yang dihadapi masyarakat yang berorientasi pada pemberdayaan masyarakat.

Ekonomi merupakan ilmu pengetahuan tentang periwisata dan persoalan yang berkaitan dengan upaya manusia secara perorangan (pribadi), kelompok (keluarga, suku bangsa, organisasi) dalam memenuhi kebutuhan yang tidak terbatas yang dihadapkan pada sumber yang terbatas. Atau suatu ilmu yang mempelajari tentang perilaku manusia yang berkaitan dengan pengalokasian sumberdaya dalam rangka memenuhi kebutuhan bagaimana manusia memenuhi kebutuhan pengalokasian sumberdaya tersebut sangat tergantung pada sistem nilai yang mengatur prilakunya. Ketentuan nilai mengenai benar dan salah, baik dan buruk. Akan tetapi dasar penelitian nilai tersebut dibuat untuk mengatur prilaku manusia yang bervariasi antara individu dengan masyarakatnya.

Jadi ekonomi merupakan ilmu yang mempelajari tentang upaya manusia dalam memenuhi kebutuhan hidupnya dengan memanfaatkan sumberdaya yang ada dan tergantung pada sistem nilai yang mengatur prilakunya dalam pengalokasian sumberdaya mengenai benar atau salah, baik dan buruk.

Menurut pandangan Islam, ekonomi harus dijalankan dengan cara islami yang mengatur kehidupan perekonomian, yaitu dengan ketelitian, cara berfikir yang berpaku pada nilai-nilai moral Islam dan nilai-nilai ekonomi. Sebagaimana Manan dalam Heri Sudarsonno mengatakan bahwa ekonomi Islam merupakan ilmu pengetahuan sosial yang mempelajari masalah-masalah ekonomi rakyat yang di ilhami oleh nilai-nilai Islam.

Ekonomi Islam juga bermakna pengetahuan dan aplikasi dari anjuran dan aturan syari'ah yang mencegah ketidakadilan dalam memperoleh sumber-sumber daya material sehingga tercipta kepuasaan manusia dan memungkinkan mereka menjalankan perintah Allah dan masyarakat.

Berdasarkan beberapa pendapat di atas, maka dapat dipahami bahwa pemberdayaan ekonomi umat terkait erat dengan sumberdaya manusia (human reseorces development), dimana sumberdaya manusia menjadi aspek sentral bagi kelangsungan perekonomian umat Islam.

Peranan Koperasi Syariah BTM Lampung dalam pemberdayaan UKM menurut perspektif ekonomi Islam yaitu koperasi syariah berdasarkan al-Qur'an dan as-Sunah yaitu: Saling tolong menolong (ta'awun) dan saling menguatkan (takaful) yang didasarkan pada al-Quran surat al-Maidah (5) ayat 2. Ayat al-Quran di atas kiranya dapat dipahami bahwa tolong menolong dalam kebajikan dan dalam ketakwaan dianjurkan oleh Allah. Koperasi merupakan salah satu bentuk tolong-menolong, kerjasama, dan saling menutupi kebutuhan. Menutupi kebutuhan dan tolong-menolong kebajikan adalah salah satu wasilah untuk mencapai ketakwaan yang sempurna (haqqa tuqatih). Koperasi Syariah BTM Lampung dalam pemberian dana pada UKM berdasarkan prinsip tolongmenolong kepada anggotanya. Anggota yang membutuhkan dana sebagai dana talangan penarikan tabungan pada saat menjelang Ramadhan atau menjelang hari raya idhul fitri.

Selain unsur tolong menolong, koperasi syariah BTM Bandar Lampung juga menjunjung tinggi keadilan serta menolak setiap bentuk ribawi dan pemusatan sumber dana ekonomi pada segelintir orang atau sekelompok orang saja. Hal ini di dasarkan pada al-Quran surat al-Rum ayat 39. Ayat tersebut merupakan ayat yang menerangkan hukum larangan riba. Riba dipertentangkan pengertiannya dengan zakat. Riba tidak menambah sesuatu nilai tambah dalam pandangan Allah. Riba hanya menambah nilai pada kekayaan 
seseorang. Sedangkan zakat yang diberikan kepada orang lain mengurangi harta seseorang tetapi memberikan nilai tambah pada amalan seseorang.

\section{E. KESIMPULAN}

Berdasarkan hasil analisa data yang telah dijabarkan sebelumnya, maka hasil temuan penulis bahwa koperasi syariah memiliki potensi dan peranan yang sangat besar dalam upaya mendukung pemberdayaan UKM di Bandar Lampung, hal ini terlihat darui data laporan pembiayaan UKM di lokasi penelitian sebelum dan sesudah mendapatkan pembiyaan dari Koperasi Syariah BTM yang juga membantu pengembangan UKM dan praktek pemberdayaan UKM yang dilakukan oleh Koperasi Syariah BTM Bandar Lampung yang memberikan pembiayaan jasa layanan kepada masyarakat yaitu program kredit usaha dengan nisbah bagi hasil yang disepakati 30:70 dengan marjin 18\% pertahun. Perkembangan ini dapat dilihat dari plafon laporan pembiayaan UKM yang mengalami peningkatan sangat baik dari tahun ketahun, dan diprioritaskan untuk sektor layanan jasa, perdaganga dan pertanian. Sehingga dengan adanya pemberdayaan UKM yang disalurkan oleh Koperasi Syariah BTM Bandar Lampung sangat berpengaruh besar bagi nasabah, terutama terbantu dalam pengembangan usahanya.

Peranan Koperasi Syariah BTM Lampung dalam pemberdayaan UKM menurut perspektif ekonomi Islam yaitu koperasi syariah berdasarkan al-Quran dan as-Sunah yaitu: Saling tolong menolong (ta'awun) dan saling menguatkan (takaful) yang didasarkan pada al-Quran surat al-Maidah (5) ayat 2. Koperasi syariah BTM Bandar Lampung juga menjunjung tinggi keadilan serta menolak setiap bentuk ribawi dan pemusatan sumber dana ekonomi pada segelintir orang atau sekelompok orang saja. Hal ini di dasarkan pada al-Quran surat al-Rum ayat 39.

\section{DAFTAR PUSTAKA}

Buchori, Nur S. Koperasi Syariah. Jawa Timur: Masmedia Buana Pustaka, 2009.

Chapra, Umar. Islam dan Tantangan Ekonomi. Jakarta: Gema Insani, 2000.

Hasan, M. Ali. Berbagai Macam Transaksi Dalam Islam. Jakarta: Raja Grafindo Persada, 2003.

Kasmir. Bank dan Lembaga Keuangan Lainnya. Jakarta: Rajawali Pers, 2013.

Lubis, Ibrahim. Ekonomi Islam Suatu Pengantar. Jakarta: Kalam Mulai, 1994.

Rijal Yahya dkk. Akuntansi Perbankan Syariah Teori dan Praktik, 2016.

Satio, Arifin, dan Halomon Tamba. Koperasi Teori dan Praktik. Jakarta: Glora Aksara Pratama, 2001.

Sofiani, Triana. "Kontruksi Norma Hukum Koperasi Syariah dalam Kerangka Sistem Hukum Koperasi Nasional.” Jurnal Hukum Islam 12 (Desember 2014).

Widiyanti, Ninik, dan Y. W. Sunindhia. Koperasi dan Perekonomian Indonesia, 2008. 
Nur Syamsiyah, Annisa Martina Syahrir, Is Susanto

Al Amin: Jurnal Kajian Ilmu dan Budaya Islam, Volume 2, No 1, 2019|73 